\title{
Paraneoplastic digital necrosis associated with rectum carcinoma
}

\section{Rektum kanseri ilişkili paraneoplastik dijital nekroz}

Ali Alkan ${ }^{1}$, Seçkin özgül ${ }^{2}$, Arzu Yaşar ${ }^{1}$, Ebru Karcl $^{1}$, Elif Köksoy ${ }^{1}$, Güngör Utkan ${ }^{1}$

\begin{abstract}
Paraneoplastic vascular pathologies are rare in daily practice. There is limited data about this phenomenon. Patient with a diagnosis of metastatic rectum carcinoma presented with digital necrosis. The work up for vascular and rheumatological pathology was inconclusive. Lesions progressively improved with steroid therapy. Paraneoplastic vascular lesions are rare in oncology practice. Our case points out important parts of a rare clinical entity. $J$ Clin Exp Invest 2015; 6 (4): 391-392
\end{abstract}

Key words: Rectum cancer, digital necrosis, paraneoplastic

\section{INTRODUCTION}

Paraneoplastic syndromes are common in our daily oncology practice. While endocrine and hematological pathologies are encountered, rarely vascular pathologies are seen. Paraneoplastic vasculitic syndromes are rare and difficult to diagnose. Here we present a paraneoplastic digital necrosis presenting with metastatic rectum carcinoma.

\section{CASE PRESENTATION}

A 62 years old female patient presented with constipation and hematochezia. Colonoscopy revealed an obstructing mass originating from rectum. Biopsy of the lesion showed an adenocarcinoma of rectum. There were no metastatic lesions in the radiological workup. She was operated with low anterior resection and lymph node dissection. The histopathology showed an adenocarcinoma, grade 2 , invading through the muscularis propria into the peri-colorectal tissues without lymph node metastasis. T3N0M0

\section{ÖZET}

Paraneoplastik vasküler patolojiler günlük pratikte nadirdir ve bu konuda bilgi sınırlıdır. Burada rektum kanseri ilişkili paraneoplastik dijital nekroz vakası sunulmuştur. Metastatik rektum kanseri ile izlenmekte olan hasta dijital nekroz ile başvurdu. Yapılan değerlendirmede vasküler veya romatolojik hastalığa ait bulgu saptanmadı. Lezyonlar steroid tedavisi ile geriledi. Onkoloji pratiğinde paraneoplastik vasküler lezyonlar oldukça nadirdi. Vakamız bu nadir patolojinin klinik özellikleri, tanısı ve tedavisine dikkat çekmektedir.

Anahtar kelimeler: Rektum kanseri, dijital nekroz, paraneoplastik sendrom

rectum cancer patient was followed with adjuvant chemo-radiotherapy. The patient was treated with per oral capecitabine $2 \times 825 \mathrm{mg} / \mathrm{m}^{2} /$ day during radiotherapy and 10 cycles of FOLFOX- 6 regimen (5-5-Fluorouracil, folinic acid and oxaliplatin). After 2 year follow-up, pulmonary metastatic lesion ensued and patient was treated with 5-FU, folinic acid and oxaliplatin regimen for palliative intent. Partial response was achieved after 6 courses of chemotherapy. Therapy was stopped due to incompliance of the patient and an chemo-free observation period was planned. After 3 months, the pulmonary lesions were stable and the patient was monitored with 3 months intervals.

At the $6^{\text {th }}$ month in the chemo-free period, the patient was presented with headache and somnolence. Progressive neurological deterioration conveyed us for central nervous system pathology and cranial imaging showed multiple nodular lesions in the cerebral and cerebellar hemispheres. Patient was followed with radiotherapy and anti-edema

${ }^{1}$ Ankara Üniversitesi Tıp Fakültesi Hastanesi, Tıbbi Onkoloji Bilim Dalı, Ankara, Türkiye

${ }^{2}$ Ankara Üniversitesi Tıp Fakültesi Hastanesi, Iç Hastalıkları Anabilim Dalı Ankara, Türkiye

Correspondence: Ali Alkan,

Ankara Üniversitesi Tıp Fakültesi Hastanesi, Tıbbi Onkoloji Bilim Dalı, Ankara, Türkiye Email: alkanali@yahoo.com

Received: 15.07.2015, Accepted: 19.10.2015

Copyright (C) JCEI / Journal of Clinical and Experimental Investigations 2015, All rights reserved 
therapy. During this progressive course of the disease, progressive necrotic lesions appeared on the tips of the fingers and toes (Figure 1). Patient presented with two weeks of history starting from the fingers and progressing to toes. The necrotic lesion was painless and arterial pulses were palpable. Cardiovascular system evaluation was inconclusive. To exclude vascular pathology arterial and venous Doppler ultrasonography were performed. There was no vascular pathology. The echocardiography was normal without any valvular pathology, vegetations of atrial septal defect.

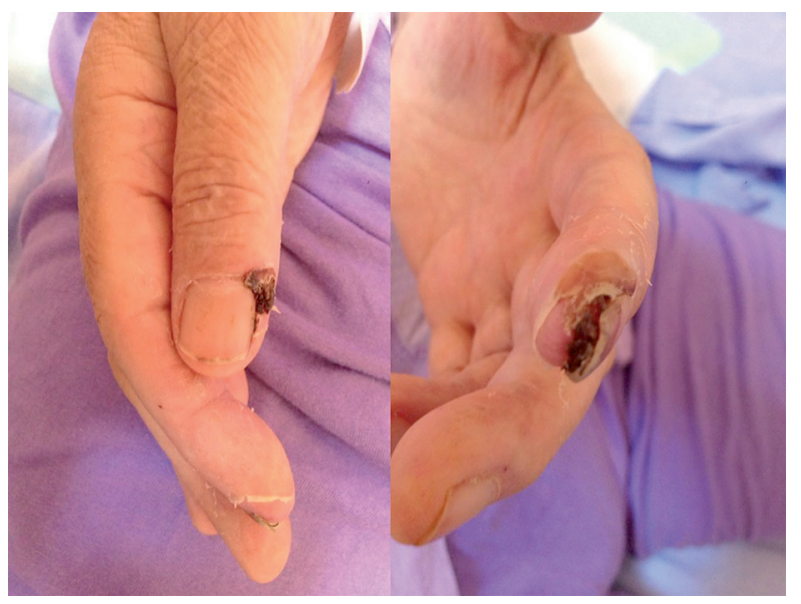

Figure 1. Necrotic lesion on the tip of left index finger and right thumb

The connective tissue disorder workup was again inconclusive. Rheumatoid factor, ANA, AntiDsDNA, SS-A, SS-B, SCL-70, anti-topoisomerase, C3, C4, cryoglobulin, lupus anticoagulant, p-ANCA, c-ANCA, capillaroscopy were all normal. Viral serology for HBV, HCV, CMV, herpes virus was normal. The association with the cytotoxic drugs was ignored due to a 6 month of chemo-free period.

The patient was followed with the diagnosis of paraneoplastic digital necrosis and the lesions improved with dexamethasone used as an anti-edema therapy in one week period without scar tissue. The lesions weren't encountered again during follow-up.

\section{DISCUSSION}

Numerous paraneoplastic syndromes are encountered in oncology practice mostly associated with lung cancer. The cancer and digital ischemia association was first reported by O'Connor in 1884 in a patient with breast cancer. Since then paraneoplastic vasculitic pathologies have been reported but the etiopathogenesis is still a mystery. The most suspected mechanism for this paraneoplastic phenomenon is the autoimmune reaction induced by tumor antigens. Digital vasospasm provoked by sympathetic hyperactivity and digital artery obstruction as a result of hyperviscosity and arteritis are other possible mechanisms [1].

Digital necrosis as a paraneoplastic syndrome has been reported in literature in different pathologies. Ovarian carcinoma is the mostly related pathology. Association also with lung, tonsillary, renal carcinoma, leukemia, lymphoma, small bowel carcinoid have been reported [2,3]. In most of the reported cases, digital necrosis is the presenting symptom of the malignancy and addition of steroid to chemotherapeutics have provided symptomatic relieve and regression of digital lesions. Drug related vasculitis was well defined, especially with antibiotics and anti-TNF drugs [1]. Chemotherapy related vasculitic events are rarely reported. Hill and Pellegrini has been reported patients with small vessel vasculitis associated with fluorouracil [2,3]. In our patient, we excluded the diagnosis of drug related vasculitis due to 6 months chemo-free period and the absence of any drugs that can be associated with the vasculitic lesions.

Our case is accepted as a paraneoplastic pathology, after exclusion of possible cardiovascular and connective tissue disorders. The anti-edema therapy with $24 \mathrm{mg}$ dexamethasone daily provides improvement in the lesions. To the best of our knowledge our case is the first reported digital necrosis associated with colorectal carcinoma.

\section{REFERENCES}

1. Taylor L, Hauty MG, Edwards JM, Porter JM. Digital ischemia as a manifestation of malignancy. Ann Surg 1987;206:62-68.

2. Wright JR, Gudelis S. Digital necrosis associated with squamous cell carcinoma of the tonsil: Head \& Neck 2002;24:1019-1021.

3. Petri M, Fye KH. Digital necrosis: a paraneoplastic syndrome. J Rheumatol 1985;12:800-802.

4. Radic M, Kaliterna DM, Radic J. Drug-induced vasculitis: a clinical and pathological review. Neth J Med 2012;70:12-17.

5. Hill SE, Phillips R, Francis N, Agnew K. Small-vessel vasculitis following treatment with combination 5-fluorouracil/folinic acid and oxaliplatin. Clin Exp Dermatol 2009;34:103-105.

6. Pellegrini F, Astorino S, Castaldi N, et al. Small vessel vasculitis related to 5-fluorouracil and folinic acid. Eur J Dermatol 2010;20:862-863. 